\title{
Sunflower crop and climate change: vulnerability, adaptation, and mitigation potential from case-studies in Europe
}

\author{
Philippe Debaeke ${ }^{1, *}$, Pierre Casadebaig ${ }^{1}$, Francis Flenet ${ }^{2}$ and Nicolas Langlade ${ }^{3}$ \\ ${ }^{1}$ INRA, UMR AGIR, CS 52627, 31326 Castanet-Tolosan, France \\ 2 Terres Inovia, Centre de Grignon, 78850 Thiverval-Grignon, France \\ ${ }^{3}$ LIPM, Université de Toulouse,INRA, CNRS, 31326 Castanet-Tolosan, France
}

Received 18 October 2016 - Accepted 1 December 2016

\begin{abstract}
Climate change is characterized by higher temperatures, elevated atmospheric $\mathrm{CO}_{2}$ concentrations, extreme climatic hazards, and less water available for agriculture. Sunflower, a springsown crop often cultivated in southern and eastern regions of Europe, could be more vulnerable to the direct effect of heat stress at anthesis and drought during its growing cycle, both factors resulting in severe yield loss, oil content decrease, and fatty acid alterations. Adaptations through breeding (earliness, stress tolerance), crop management (planting dates), and shifting of growing areas could be developed, assessed and combined to partly cope with these negative impacts. New cultivation opportunities could be expected in northern parts of Europe where sunflower is not grown presently and where it could usefully contribute to diversify cereal-based cropping systems. In addition, sunflower crop could participate to the mitigation solution as a low greenhouse gas emitter compared to cereals and oilseed rape. Sunflower crop models should be revised to account for these emerging environmental factors in order to reduce the uncertainties in yield and oil predictions. The future of sunflower in Europe is probably related to its potential adaptation to climate change but also to its competitiveness and attractiveness for food and energy.
\end{abstract}

Keywords: $\mathrm{CO}_{2} /$ temperature / crop model / biotic stress / water deficit

\begin{abstract}
Résumé - Culture du tournesol et changement climatique : vulnérabilité, adaptation et potentiel d'atténuation via des études de cas en Europe. Le changement climatique se caractérise par des températures élevées, de plus fortes concentrations atmosphériques en $\mathrm{CO}_{2}$, des risques climatiques extrêmes et moins d'eau disponible pour l'agriculture. Le tournesol, culture semée au printemps dans le sud et l'est de l'Europe, pourrait être plus exposé à l'avenir aux fortes températures et à un déficit hydrique marqué dès la floraison, avec pour conséquences des pertes de rendement, une diminution de la teneur en huile et une altération de la composition en acides gras. Des adaptations sont possibles à court et moyen terme par la sélection (précocité, tolérance aux stress), la conduite de culture (date de semis) et le déplacement des zones de production, permettant de faire face en partie aux impacts négatifs attendus. Ainsi le tournesol pourrait être cultivé plus au nord participant utilement à la nécessaire diversification des bassins céréaliers. En outre, la culture de tournesol étant faiblement émettrice de gaz à effet de serre par rapport aux céréales ou au colza pourrait contribuer davantage à la solution climatique apportée par l'agriculture. Les modèles de culture devraient être revus pour mieux tenir compte de ces facteurs environnementaux émergents si l'on veut réduire les incertitudes dans les prédictions de rendement et de teneur en huile. L'avenir du tournesol en Europe est probablement lié à son potentiel d'adaptation au changement climatique, mais dépendra aussi de sa compétitivité et de son attractivité en tant que fournisseur d'énergie et d'aliments.
\end{abstract}

Mots clés : $\mathrm{CO}_{2} /$ temperature / modèle de culture / stress biotique / déficit hydrique

\section{Introduction}

In Europe, sunflower is mostly cultivated in southern and eastern regions. In 2013, Russia, Ukraine (together 49\%,

\footnotetext{
* Correspondence: philippe.debaeke@inra.fr
}

17.7 Mt), and UE-28 (19\%, 6.8 Mt) were the largest sunflower grain producers in the world accounting for $68 \%$ of global volume. Sunflower crop is covering more than $4.5 \mathrm{M}$ ha in UE-28: Romania, Spain, France, Bulgaria, and Hungary being the main contributors ( $90 \%$ of the UE-28 area). However, in most of these countries, there subsists major yield gaps (national yield between 1.1 and $2.4 \mathrm{tha}^{-1}$ ) and the slope of 
actual yield progress is rather flat in spite of the steadily genetic improvement (e.g., Salvi and Pouzet, 2010 for France). Climate change could be partly responsible for yield limitation as was observed for wheat (Brisson et al., 2010) although changes in cultural practices and land use could contribute as well.

The Intergovernmental Panel on Climate Change (IPCC) has predicted that the atmospheric $\mathrm{CO}_{2}$ concentration (400 ppm today) may increase up to $660 \mathrm{ppm}$ and $790 \mathrm{ppm}$ in 2060 and 2090, respectively (IPCC, 2007, 2014). This is expected to raise global temperatures due to the $\mathrm{CO}_{2}$ capacity to absorb infrared light and possibly change the precipitation patterns. In the period 1901-2005, the average annual temperature rose throughout Europe by $0.9^{\circ} \mathrm{C}$ (Lotze-Campen, 2011); since the end of the 80 s, the elevation of air temperature was clearly observed throughout Europe and the climatologists are speaking of climatic trend and not of natural inter-annual climatic variability.

Global Climate Models (GCMs) indicate strongest warming over eastern and northern Europe during winter and over western and southern Europe during summer (IPCC, 2007, 2014). Especially in the southwestern parts (France, Spain, and Portugal), increase in average summer temperatures may exceed $6^{\circ} \mathrm{C}$ by the end of the century. In addition, maximum temperatures could increase much more in southern and central Europe than in northern parts. However, annual precipitation trends as well as seasonal precipitation patterns should vary regionally (Lotze-Campen, 2011). In northern Europe and most of the Atlantic region, mean winter precipitation should increase contrary to the Mediterranean area (especially its eastern part). Summer precipitation will decrease substantially in southern and central Europe and to a smaller degree in northern Europe. However, during spring and autumn, precipitation change should be marginal. Overall, the intensity of daily precipitation should increase substantially. Heat waves and droughts will occur more often (especially in the Mediterranean area and much of eastern Europe) due to the combined effect of warmer temperatures and less summer precipitation (Lotze-Campen, 2011). In addition, droughts will start earlier and last longer.

Therefore, in its traditional production areas, sunflower crop as a spring-and summer-sown crop will be exposed to major climate change and potentially impacted by water shortage and high temperatures (see below). Sunflower is commonly viewed as a drought-tolerant crop and consequently as a cropping opportunity for regions where water resources (used for irrigation) are decreasing and in situations where soil water deficit is expected to increase dramatically (García-Vila et al., 2012). When water is fully available, maize or soybean are preferred, and sunflower is often restricted to marginal areas or non-irrigated farms (Debaeke et al., 2008). However, if climate change is a threat for sunflower in southern and eastern regions, it could also offer new cropping opportunities in northern parts of Europe. As the only summer oilseed crop in Europe, sunflower could break winter crop rotations where non-sustainable use of fertilizers and pesticides are currently practised.

For the major crops (wheat, rice, and maize) in tropical and temperate regions, local temperature increases of $2{ }^{\circ} \mathrm{C}$ or more, induced by climate change, will negatively impact yields if there is no adaptation (Porter et al., 2014). No such broad evaluation was produced for sunflower crop in the last IPCC reports and scientific reviews (Yadav et al., 2011). This justifies this preliminary review:

- of the impacts of climate change on sunflower grain and oil yields,

- of possible adaptation options, and

- of the contribution of sunflower to greenhouse gases (GHG) emissions.

\section{Crop suitability}

Sunflower cultivation is currently limited to southern Europe and parts of central/eastern Europe mainly for temperature reasons. A northward shift of southern crops suitability area is likely to occur as temperature steadily raises (Carter et al., 1991; Olesen and Bindi, 2002). It is commonly admitted that the area suitable for crop growing may shift northward by $180 \mathrm{~km}$ per $1^{\circ} \mathrm{C}$ increase in annual mean temperature (Seguin, 2003). In addition, sunflower could also become viable at higher altitudes than presently (shift of $+150 \mathrm{~m}$ per $1^{\circ} \mathrm{C}$ increase). In the northern regions and in the continental part of Europe, warming will extend the length of the potential growing season allowing earlier planting and harvesting. Drier conditions in those areas could also increase the soil workability in spring.

Most of the crop suitability studies are based on thermal requirements (base temperature and growing degree-days). Tuck et al. (2006) used climate scenarios based on four IPCC SRES emission scenarios (A1, A2, B1, and B2) implemented by four GCMs (HadCM3, CSIRO2, PCM, and CGCM2) to predict the potential distribution of bioenergy crops in Europe under present and future climate. Their assumptions were that sunflower requires between 350 and $1500 \mathrm{~mm}$ of rain per year, with minimum and maximum monthly temperatures of 15 and $39^{\circ} \mathrm{C}$, respectively, between April and September. According to all climatic models, sunflower will continue to be potentially grown in over $60 \%$ of southern Europe $\left(35-44^{\circ} \mathrm{N}\right)$. The four models predicted very different potential distributions in Central Europe by the 2080s due to the different combined predictions of temperature increase, and change in precipitation among them: a $25 \%$ increase in $45-54^{\circ} \mathrm{N}$ by the 2080 s due to increased summer temperatures (CGCM2 and HadCM3) vs. a decline of up to $25 \%$ in this latitude (CSIRO and PCMA).

Anyway, sunflower should take advantage of the improved thermal regime (higher summer temperatures) at northern latitudes. Sunflower is currently grown up of $62^{\circ} \mathrm{N}$ in the most temperature favored regions of southern Finland (PeltonenSainio et al., 2009). Requiring $1100^{\circ} \mathrm{Cd}\left(\mathrm{Tb}=5^{\circ} \mathrm{C}\right)$ for completing their cycle (Niemelä and Tulisalo, 2000), very early sunflower varieties might be grown northern than $65^{\circ} \mathrm{N}$ in the next decades. Some studies explicitly considered the extension of sunflower crop to southern England as a possible adaptation to climate change (Bellarby et al., 2010). The projections from UKCIP02 data indicate that the area suitable for sunflower production (using very early cultivars) will increase to approximately $79 \%$ of the land area of England by 2050 (Cook, 2009). However, when considering competition with other break crops at farm level, Gibbons and Ramsden (2008) concluded that sunflower area could increase from $0.3 \%$ in the baseline through $0.4 \%$ in the 2020 s to $1.9 \%$ in the 2050s, which looks quite minor. Hence, while the sunflower 
area is sensitive to the degree of climate change, there is little evidence of a 'tipping point' for a shift in break crops, within the range of climate outcomes modeled.

\section{Impacts on crop yield}

At southern latitudes, temperature increases, precipitation decreases as well as increases in climatic inter-annual variability, and a higher frequency of extreme events are to be expected (IPCC, 2014). These combined changes will lead to a shorter growing season (especially grain filling phase), increased water deficit and heat stress, which will theoretically reduce yields, lead to higher yield variability, and probably reduce the agricultural area of this traditional crop in regions as Italy, Spain, Portugal, and southwestern France (Moriondo and Bindi, 2007; Moriondo et al., 2011).

To document these threats and be more accurate at regional level, several simulation-based studies involving sunflower were recently published (Tab. 1).

The most complete and recent one (AVEMAC project) was produced by JRC (EU) in 2012 (Donatelli et al., 2012, 2015). Two GCMs were used: Hadley CM3 (warm scenario) and ECHAM5 (cold); yield simulations were performed with the CropSyst model (Stöckle et al., 2003) at 2020 and 2030 horizons with or without technical adaptations (maturity group and sowing date). Both potential and water-limited yields were simulated for NUTS2 regions of EU-28. The average $\left[\mathrm{CO}_{2}\right]$ in the atmosphere was set to $355 \mathrm{ppm}$ for 2000 (baseline), 400 ppm for 2020 and 420 ppm for 2030 , accordingly to IPCC assumptions.

In terms of potential yield, the yield improvement was simulated by 2020 compared to baseline time horizon in a magnitude of $5-10 \%$ or no change in whole Europe except decline in some places of Portugal, Romania, and Bulgaria (Donatelli et al., 2012). On the other hand, in 2030 time window, a detrimental effect of climate change by 5-20\% was simulated in southern parts of Europe (Spain, Italy, Hungary, Romania, and Bulgaria) which might be due to the reduction of radiation intercepted by sunflower canopies (with higher seasonal temperature causing an acceleration of senescence) and to the depressive effect of high temperatures on photosynthetic activity. On the contrary, the yield gain in northern France and Germany suggests that global warming may increase the length of the growing period and make cultivation conditions more favorable for sunflower growing under these latitudes as discussed above. From the warm 2030 scenario, a potential decrease in sunflower production of around $10 \%$ was expected for all important Spanish regions and from $4 \%$ to $8 \%$ in France depending on the regions (Fig. 1). Almost all regions of eastern Europe (Hungary, Bulgaria, and Romania) could be affected by a significant decrease of $12-14 \%$ in 2030 . The analysis for the cold scenario anticipates to 2020 the variations foreseen in the warm scenario in 2030 for Spain whereas in France cold and warm scenarios resulted in the same yield estimations for 2030 (Fig. 1).

Considering water-limited yields in 2020 (Fig. 2), the simulations show an improvement (with HadCM3) of sunflower yield at southern latitudes (Spain, Italy, Romania, and Bulgaria) with some patches of decline in France and Germany in 2020 (Donatelli et al., 2012). These improvements can be directly linked to the higher precipitation prediction compared to baseline. By 2030 the improvements should get milder in southern European countries, and eastern countries should see a 10-30\% yield decline (Fig. 2). Higher evapotranspiration coupled with less rainfall could explain this negative impact.

Since the pioneering study of Harrison and Butterfield (1996), several other studies have simulated the impact of future climate on sunflower yield at local, regional or national levels (Tab. 1). Attention must be drawn as crop simulation models, GCMs, Regional Climate Models (RCMs) and Greenhouse Gas Emissions (GGE) scenarios differed among studies, which led to contradictory and uncertain conclusions.

Tubiello et al. (2000) investigated with CropSyst and two GCMs the potential effects of doubling the atmospheric $\left[\mathrm{CO}_{2}\right]$ from 350 to $700 \mathrm{ppm}$ on sunflower yields at two Italian locations. They concluded to limited changes for non-irrigated sunflower as a consequence of sufficient soil water refillment during winter fallow period.

Guilioni et al. (2010) used both SUNFLO and STICS crop models (both including $\mathrm{CO}_{2}$ effects) to simulate baseline, next and far future climate (CLIMATOR project). They concluded to minor changes for 12 locations in France, the positive effects of increased atmospheric $\left[\mathrm{CO}_{2}\right]$ compensating for negative effects of water stress. However they predicted an increase of inter-annual variability during vegetative period. The potential extension of sunflower crop northward in France was confirmed as well. Crop duration was reduced by $4-6$ days at flowering time and by 7-12 days at harvest per $1{ }^{\circ} \mathrm{C}$ increase of air temperature, as a function of RCM and genotype considered. The number of hot days (maximal temperature over $32^{\circ} \mathrm{C}$ ) during grain filling could increase from 8 (baseline) to 22 (far future) in Toulouse (southwestern France).

At the European level, Moriondo et al. (2011) assessed the direct impact of extreme climate events (i.e. heat stress at anthesis stage) by using the outputs of HadCM3P regional climate model as drivers of a modified version of CropSyst model. The authors concluded that the increase in highest temperatures for the period 2071-2100 under A2 and B2 scenarios would result in an increase in the frequency of heat stress during anthesis with respect to the baseline (1961-1990). The yield losses in the Mediterranean area changed on average from $14 \%$ to $34 \%$ (A2 and B2 scenarios), and the risk of low yields (i.e. below $1.8 \mathrm{tha}^{-1}$ ) increased from $8 \%$ to $24 \%$, where the highest differences were observed in the northeastern and southeastern regions and in the flat areas. In Portugal, Valverde et al. (2015) used a water balance approach combined with the Stewart method and CMIP3 climate projections datasets and simulated yield losses between $6 \%$ and $10 \%$ for the 2011-2041 period, and 11-19\% for the 2041-2070 period. In these southern regions, sunflower will be more prone to the direct effect of heat stress at anthesis and drought during its growing cycle if no adaptation is introduced.

A recent study used the AQUACROP model from the FAO (Raes et al., 2009) to simulate the yield and production of sunflower crop in Ukraine, Russia and Kazakhstan at the horizon 2046-2065 (Olivier et al., 2016). Two climatic scenarios were tested: moderate warming according to CGM31 climatic model $\left(+2.4^{\circ} \mathrm{C}\right.$ in 2065$)$, severe warming according to MIROC3.2 climatic model $\left(+4.3^{\circ} \mathrm{C}\right.$ in 2065$)$. Only temperature and evapotranspiration were considered, precipitation being the same as the baseline and atmospheric $\left[\mathrm{CO}_{2}\right]$ change was not included. According to the moderate 


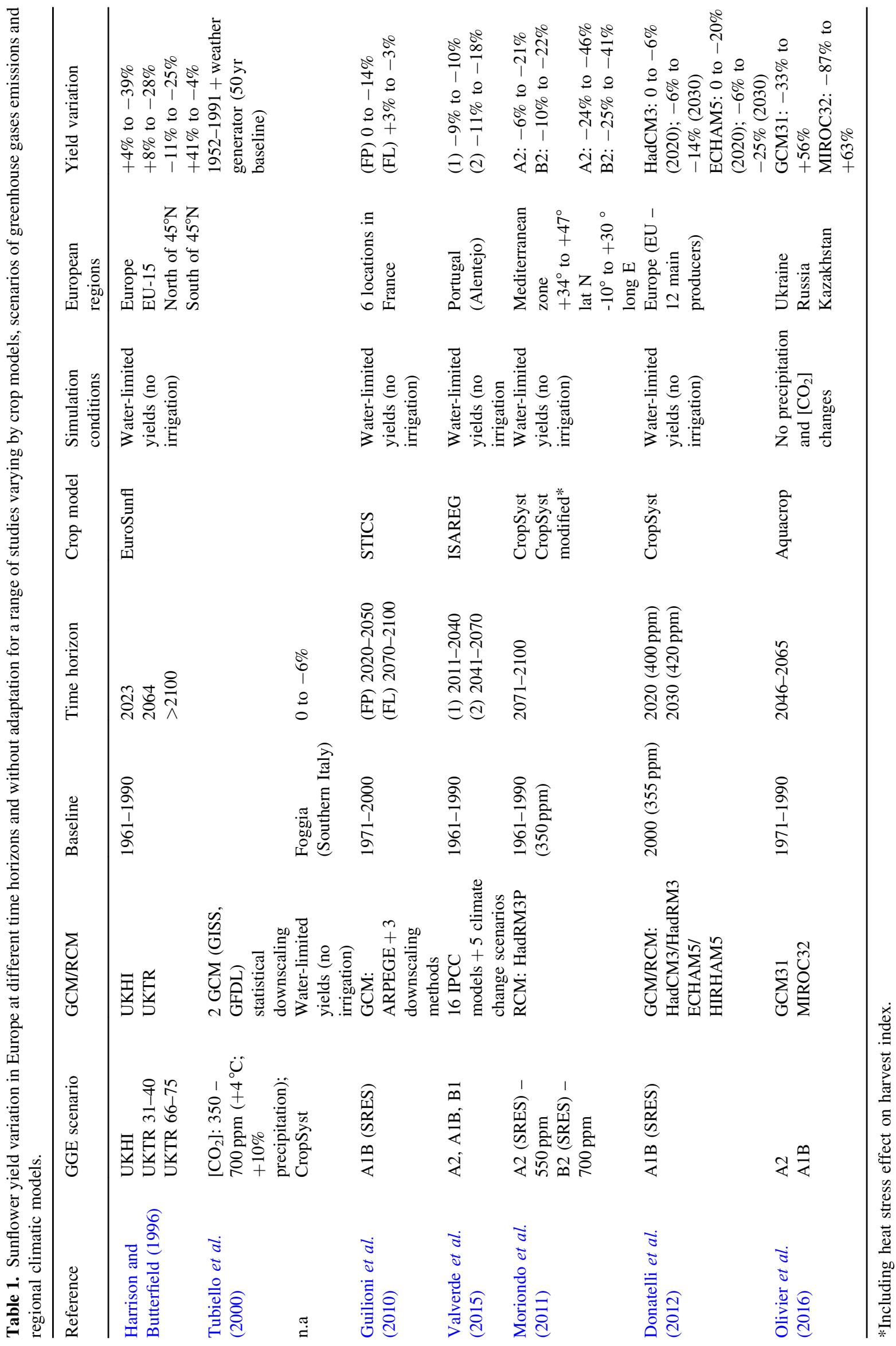




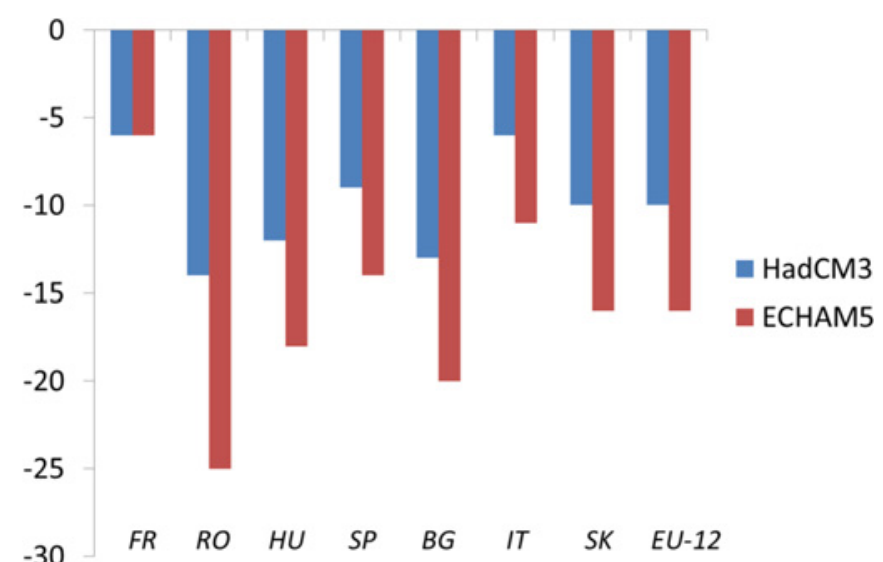

Fig. 1. Variation of sunflower production at 2030 horizon for 7 countries producing sunflower and for Europe (12 countries). From Donatelli et al. (2012). FR, France; RO, Romania; HU, Hungary; SP, Spain; BG, Bulgaria; IT, Italy; SK, Slovakia; EU-12 (7 previous countries + Austria, Czech Republic, Greece, Portugal, Slovenia).

scenario, total crop production would decrease globally by $3 \%$ (Russia and Kazakhstan production would be affected while production would increase in Ukraine). According to the severe scenario, total production would decrease by $50 \%$ with dramatic consequences on the world market as Ukraine would be deeply impacted.

\section{Crop models for exploring the impacts of climate change}

Simple models have been used to map crop suitability based on growing degree-days (e.g. Tuck et al., 2006). Traditionally, yield estimation has been based on empirical data, simple evapotranspiration models and, lately, on processbased models (Garcia-Lopez et al., 2014). The impact of climate variability and climate change on grain yield and quality are now exclusively investigated using crop simulation models as recent developments and refinements have been done (algorithms, databases, climate projections).

In simulation models, crop responses to climate change are predicted by modeling physiological processes (development, growth, and yield) as a function of $\left[\mathrm{CO}_{2}\right]$ and high temperature (Free-Air $\mathrm{CO}_{2}$ Enrichment experiments, Ainsworth and Long, 2005; Temperature Free-Air Controlled Enhancement, Ottman et al., 2012).

Crop models currently used for simulating sunflower yield in response to various environments are either: (i) generic (a single mode for multiple species): STICS (Brisson et al., 2003), CropSyst (Stöckle et al., 2003; Todorovic et al., 2009; Moriondo et al., 2011), EPIC/EPIC-Phase (Kiniry et al., 1992; Cabelguenne et al., 1999), AquaCrop (Raes et al., 2009; Todorovic et al., 2009), AqYield (Constantin et al., 2015), WOFOST (Todorovic et al., 2009) or (ii) specific to sunflower crop: Oilcrop-Sun (Villalobos et al., 1996), QSUN (APSIMsunflower) (Chapman et al., 1993; Zeng et al., 2016), SUNFLO (Casadebaig et al., 2011).

Only some of these models embed equations to simulate crop response to increased $\left[\mathrm{CO}_{2}\right]$ and high temperatures, thereby enabling the risk of strongly underestimating crop

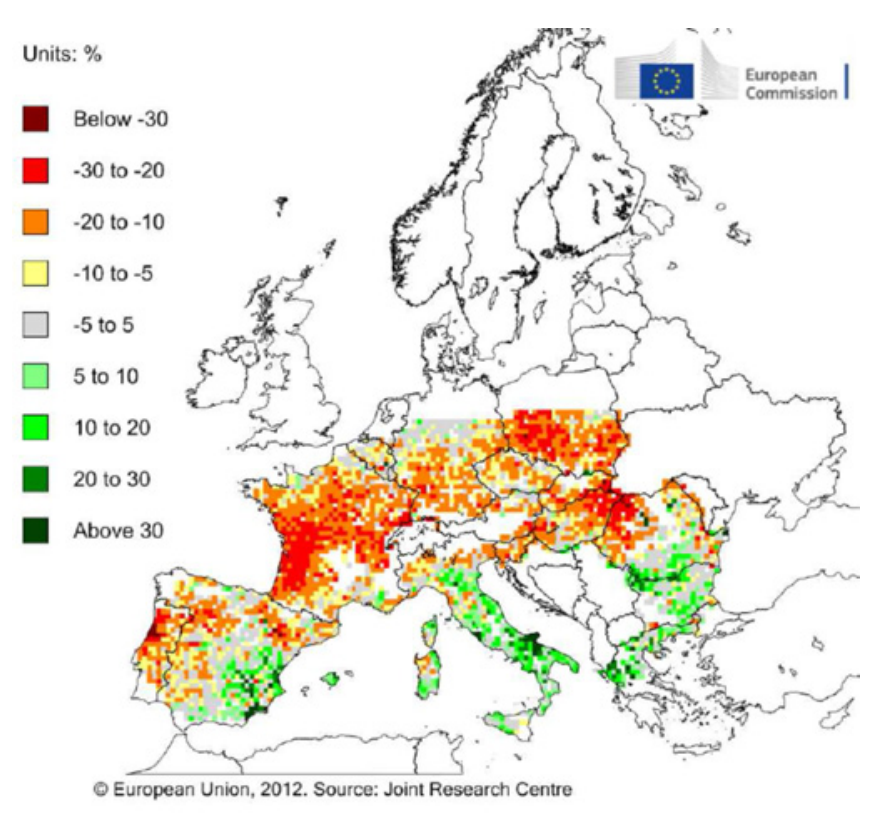

(a) HadCM3 scenario

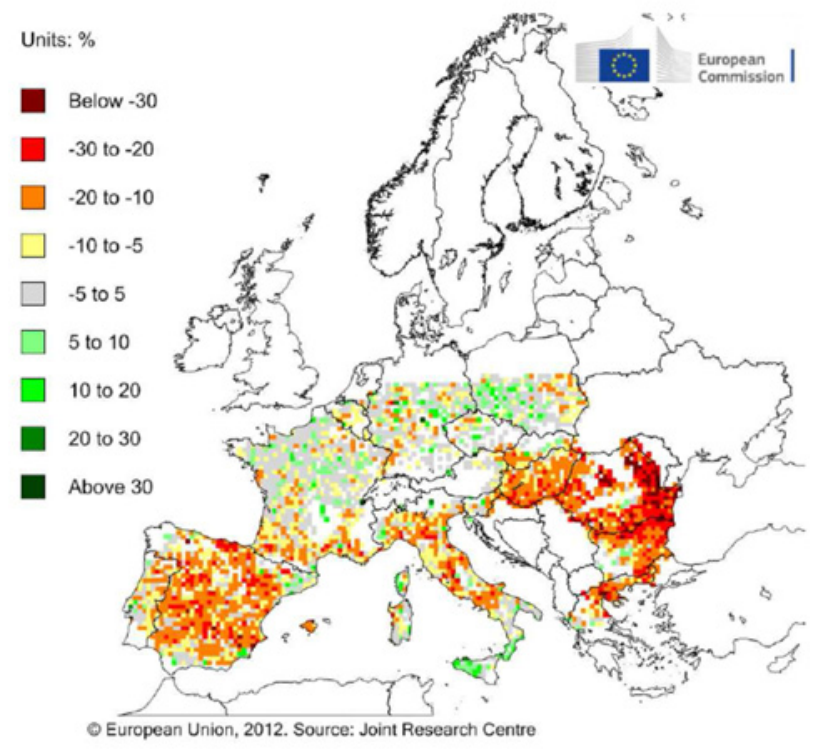

\section{(b) ECHAM5 scenario}

Fig. 2. Relative change of sunflower yield in water-limiting conditions in 2030 using the 'warm' (HadCM3) and the 'cold' (ECHAM5) realisation of scenario A1B. No adaptation strategies are considered here (from Donatelli et al., 2012).

yield losses in prospective scenarios (Moriondo et al., 2011). However, CropSyst, EPIC, and STICS models have been extensively used and include the effects of elevated $\left[\mathrm{CO}_{2}\right]$ on crop photosynthesis and transpiration. 
Consequently, more effort is still necessary to make these models operational tools for climate change impact assessment and adaptation design. To be improved, models should integrate more physiological knowledge on the single and combined effects of $\left[\mathrm{CO}_{2}\right]$, drought and temperature (e.g. temperature $\times$ drought interaction, Schoppach and Sadok, 2013) on crop production but also new outputs, as only a few models explicitly consider seed oil content (Andrianasolo et al., 2016a).

A review by Parent and Tardieu (2012) focused on the relevance of current crop models to predict the genetic variability of yield under water deficit or high temperature. Concerning temperature, processes responses are often approximated with a linear function of temperature, thereby limiting the domain of validity of the model to the range of temperature in which the response is approximately linear (Parent and Tardieu, 2012). A simple first step for sunflower models should be to use curvilinear functions, which is expected to improve the prediction of crop development in high temperature conditions.

We also identified two other targets for increasing the accuracy of models; however, probably requiring more advanced ecophysiological modeling. First, environmental factors do not drive the same responses from plants during the crop cycle, even considering only vegetative and reproductive stages (e.g. for photosynthesis and transpiration, Andrianasolo et al., 2016b). It was also reported that plants respond differently to stress patterns, i.e. long progressive $v$ s. multiple short stresses (Caldeira et al., 2014; Sadok, 2016). Current crop models implement a single plant response to each environmental factor, discarding distinct responses caused by development or multiple successive stresses (plant adaptation).

However, the current performance of sunflower crop models should be benchmarked, as it was recently done for wheat and maize in the AgMip international initiative (e.g. Martre et al., 2015) before considering further implementation of described ecophysiological refinements.

\section{Physiological impacts of climate change on productivity}

\section{$5.1 \mathrm{CO}_{2}$ fertilization effect}

Rising atmospheric $\left[\mathrm{CO}_{2}\right]$ can affect the growth and yield of C3 plants, mainly through enhancement in the rate of photosynthesis and carbon assimilation (Griffin and Seemann, 1996). Various studies have been conducted worldwide on the response of different crop species to the increase of $\left[\mathrm{CO}_{2}\right]$ which confirmed higher rate of photosynthesis, plant growth and yield due to elevated $\left[\mathrm{CO}_{2}\right]$ exposure (Ainsworth et al., 2008; Taub et al., 2008). In C3 plants such as sunflower, radiation, water and $\mathrm{N}$ use efficiencies are all expected to increase with $\left[\mathrm{CO}_{2}\right]$. It has been demonstrated that $\mathrm{C} 3$ crops plants produce more biomass and harvestable products under high $\mathrm{CO}_{2}$ environment compared with $\mathrm{C} 4$ due to the enhanced rate of photosynthesis (Long et al., 2006). There is also adequate evidence that the $\mathrm{CO}_{2}$ fertilization effect will continue for $\mathrm{C} 3$ plants at least until the $\left[\mathrm{CO}_{2}\right]$ reaches $750 \mathrm{ppm}$ (Seneweera and Norton, 2011). The extent of this increase will depend not only on the short-term stimulation of photosynthetic activity but also on longer-term acclimation responses (Sims et al., 1999). Most of the studies on plant response to elevated $\left[\mathrm{CO}_{2}\right]$ have been conducted in cereal crops (e.g. wheat, maize, rice), and very few reports are available about the response of oilseed crops, especially sunflower.

However, during the two last decades, some studies on sunflower confirmed the typical C3 response of this oilseed crop to elevated $\left[\mathrm{CO}_{2}\right]$. Exposure of sunflowers to twice higher $\mathrm{CO}_{2}$ concentration than today in large controlled-environment chambers enhanced rates of net photosynthesis in individual upper-canopy leaves by approximately 50\% (Sims et al., 1999). Cheng et al. (2000) used a whole-system gas exchange chamber and a 13C natural tracer method to observe that total daily photosynthesis, net primary production, and respiration were consistently higher under the elevated $\left[\mathrm{CO}_{2}\right]$ treatment $(750 \mathrm{ppm})$ than under the ambient $\left[\mathrm{CO}_{2}\right]$ one $(400 \mathrm{ppm})$. Using the same experimental design, Luo et al. (2000) observed that elevated $\left[\mathrm{CO}_{2}\right]$ increased canopy light utilisation by $32 \%$ and carbon uptake by fully 53\%. Again in 2012, De la Mata et al. (2012) observed that photosynthetic $\mathrm{CO}_{2}$ fixation was boosted on young leaves growing under elevated $\left[\mathrm{CO}_{2}\right]$. In an experiment where $\left[\mathrm{CO}_{2}\right]$ was increased from 399 to $746 \mathrm{ppm}$, Hui et al. (2001) measured an increase of daily total canopy carbon- and water-fluxes by $53 \%$ and $11 \%$, respectively, resulting in a $54 \%$ increase in radiation-use efficiency (RUE) and a $26 \%$ increase in water-use efficiency (WUE) by the end of the experiment. More recently Rinaldi et al. (2015) showed that an increased $\left[\mathrm{CO}_{2}\right]$ from 370 to 760 ppm led to:

- an improvement of more than $60 \%$ in the net photosynthesis rate;

- a reduction of $7 \%$ of the stomatal conductance;

- a water saving of $0.074 \mathrm{~L} \mathrm{~m}^{-2}$ (leaf) $\mathrm{h}^{-1}$ (due to the transpiration loss) and consequently

- an improvement of instantaneous water use efficiency (WUE) from 4.36 to $10.56 \mathrm{mg} \mathrm{CO}_{2} \mathrm{~g} \mathrm{H}_{2} \mathrm{O}^{-1}$.

The above findings all suggest that sunflowers should become more efficient at absorbing sunlight, using its energy to convert $\mathrm{CO}_{2}$ into carbohydrates and save water as the $\left[\mathrm{CO}_{2}\right]$ increases in the future. Consequently net photosynthetic rates and biomass production should increase as well. This was reported in several field studies in which significant increases in root and shoot biomass (from $24-68 \%$ ) as well as final grain yield were observed with elevated $\left[\mathrm{CO}_{2}\right]$ (Tab. 2).

De la Mata et al. (2012) also indicated that elevated $\left[\mathrm{CO}_{2}\right]$ could promote early leaf senescence in sunflower plants by affecting the soluble sugar levels, the $\mathrm{C} / \mathrm{N}$ ratio and the oxidative status during leaf ontogeny. Additionally, these authors concluded that elevated $\left[\mathrm{CO}_{2}\right]$ alter enzymes involved in $\mathrm{N}$ metabolism hereby boosting mobilisation of $\mathrm{N}$ in leaves and triggering early senescence in sunflower plants (De la Mata et al., 2013).

There are very few reports on the impact of high $\left[\mathrm{CO}_{2}\right]$ on the quality of sunflower seed oil. High $\left[\mathrm{CO}_{2}\right]$ could affect nutritional quality of sunflower due to the dilution effect (Jablonski et al., 2002; Taub et al., 2008). Pal et al. (2014) reported the impact of high $\left[\mathrm{CO}_{2}\right]$ exposure $(550 \mathrm{ppm})$ on oil percentage and quality of two sunflower genotypes grown 
Table 2. Sunflower yield variation for a range of experimental studies controlling $\left[\mathrm{CO}_{2}\right]$ variation.

\begin{tabular}{|c|c|c|c|c|}
\hline Reference & $\begin{array}{l}{\left[\mathrm{CO}_{2}\right] \text { conditions }} \\
(\mathrm{ppm})\end{array}$ & $\mathrm{CO}_{2}$ experimental design & $\begin{array}{l}\text { Shoot biomass variation } \\
\text { with } \mathrm{eCO}_{2}\end{array}$ & Yield variation with $\mathrm{eCO}_{2}$ \\
\hline Vanaja et al. (2011) & $380-700$ & Open top chambers & $\begin{array}{l}+24 \% \text { (well-watered }) \\
+49 \% \text { (water stressed) }\end{array}$ & n.a. \\
\hline Pal et al. (2014) & $370-550$ & Open top chambers (field) & $+61 \%$ to $+68 \%$ (2 varieties $)$ & $+35 \%$ to $+46 \%$ (2 varieties) \\
\hline Srinivasarao et al. (2016) & $380-550-700$ & Open top chambers (field) & $\begin{array}{l}+32 \%(700 \mathrm{ppm}) \\
+42 \%(550 \mathrm{ppm})\end{array}$ & n.a. \\
\hline
\end{tabular}

inside open top chambers. Elevated $\left[\mathrm{CO}_{2}\right]$ exposure significantly influenced seed yield (Tab. 2) but protein concentration decreased in the seeds $(-13 \%)$. However, oil content increased significantly in cultivar DRSF $113(15 \%)$. Carbohydrate seed reserves increased with similar magnitudes $(+13 \%)$ in both the genotypes under high $\left[\mathrm{CO}_{2}\right]$ treatment. Fatty acid composition in seed oil contained higher proportion of unsaturated fatty acids (oleic and linoleic acid) under elevated $\left[\mathrm{CO}_{2}\right]$ treatment (Pal et al., 2014).

These findings confirm that rising atmospheric $\mathrm{CO}_{2}$ in changing future climate can enhance biomass production and seed yield in sunflower but also alter protein and oil seed contents, and finally fatty acid composition. However, the beneficial effects of high $\mathrm{CO}_{2}$ can be counter-balanced by other climate factors such as the increase in atmospheric temperature and unfavorable patterns of precipitation (Ainsworth et al., 2008); this was also suggested by crop simulation studies (e.g. Guilioni et al., 2010; Donatelli et al., 2012).

\subsection{Drought effects}

Drought is the main environmental factor limiting sunflower plant growth in a wide range of environments in Europe and worldwide. Sunflower, being a crop with medium water requirements $(\mathrm{Ky}<1)$, has the ability to tolerate a short period of drought, recover partially from stress and exhibit less than proportional reductions in yield with reduced water use (García-Vila et al., 2012). By its high capacity to extract water from the subsoil, the crop has access to deeper resources (Cabelguenne and Debaeke, 1998). Its ability to regulate plant leaf area according to available water allows sunflower to control future water loss. Varieties of sunflower have been shown to exhibit contrasting responses to drought (Virgona et al., 1990, Pankovic et al., 1999). Sunflower genotypes may have conservative or productive stomatal responses resulting in various patterns of water use (Casadebaig et al., 2008; Andrianasolo et al., 2016b).

However, water stress inhibits plant growth, decreases developmental activities of the cells and tissues and causes a variety of morphological, physiological and biochemical modifications (Ahmad et al., 2014). Since water deficit is likely to increase with climate change in southern environments, negative impacts on leaf expansion, biomass accumulation and oil production are all expected. These negative consequences of drought on grain yield have been extensively studied and reviewed elsewhere in the literature (e.g. Connor and Hall, 1997; Chimenti et al., 2002; Ahmad et al., 2014) but negative impacts on oil concentration and oil quality have also been reported (Andrianasolo et al., 2014, 2016a).

\subsection{High temperature}

High temperature affects numerous biochemical and physiological traits in plants. In sunflower, compared to cereals, few efforts have been devoted to exploring the effects of heat stress, even though the crop can be damaged by high temperatures during specific sensitive stages of development (Connor and Hall, 1997).

After submitting sunflower plants to a day/night regime of $33 / 19^{\circ} \mathrm{C}$ for $16-42$ days, De la Haba et al. (2014) observed decreased leaf growth (lower specific leaf mass, reduced leaf area) and increase of soluble protein content during the leaf life span relatively to control plants $(70 \% v s .45 \%$, respectively). They suggested that high temperatures promote soluble protein degradation in leaves. It also reduces net photosynthetic rate possibly by decreasing the content of photosynthetic pigments and the stomatal conductance.

In sunflower, constant high temperature decreases final grain weight and oil yield (Harris et al., 1978). Chimenti et al. (2001) applied constant temperatures $\left(12-40^{\circ} \mathrm{C}\right)$ during grain filling which resulted in a curvilinear response of the rate of embryo filling with a peak at $25^{\circ} \mathrm{C}$; embryo-filling duration had a minimum close to $34^{\circ} \mathrm{C}$, and embryo size continuously decreased with increasing temperature above $25^{\circ} \mathrm{C}$. Direct effects of brief periods of heat stress during grain filling were investigated by Rondanini et al. (2003). They exposed the capitulae of plants growing at $25^{\circ} \mathrm{C}$ to temperatures of ca. 35 , 37 and $40^{\circ} \mathrm{C}$ for seven consecutive days during grain filling. Brief periods of heat stress resulted in a lower seed weight, a greater percentage of pericarp, a lower oil content and an altered fatty acid composition. In addition, the period from 12 to 19 days after anthesis (daa) showed the greatest sensitivity to heat stress regarding embryo and grain weight responses, whereas the period of greatest sensitivity for oil quality was from 19 to 26 daa (Rondanini et al., 2006).

Temperatures higher than $31^{\circ} \mathrm{C}$ at anthesis stage were demonstrated to be detrimental for sunflower yield because they affect pollen production and floret fertility (Chimenti and Hall, 2001). Likewise, Astiz and Hernández (2013) showed that temperatures over $26^{\circ} \mathrm{C}$ were supra-optimal for pollen production in sunflower, even under well-watered conditions. The effect of extreme temperature during anthesis was simulated by Moriondo et al. (2011) in a modified version of CropSyst crop model.

\subsection{Interactions between temperature, water and $\mathrm{CO}_{2}$}

Independently, the impacts of increased atmospheric $\left[\mathrm{CO}_{2}\right]$, heat and drought stress on crop growth and productivity 
have been well documented. Heat and drought stress frequently occur together and in the future they will be associated to elevated $\left[\mathrm{CO}_{2}\right]$. However, the interactions between these abiotic conditions and their effects on photosynthesis, plant growth and transpiration are still unclear in sunflower.

Recently Killi et al. (2016) grew two varieties of sunflower (drought tolerant and sensitive) under conditions of moderate $\left(25^{\circ} \mathrm{C}\right)$ or elevated temperature $\left(35^{\circ} \mathrm{C}\right)$ for 4 weeks prior to the imposition of water deficit. They observed than after being exposed to high temperature treatment, net photosynthetic rates and stomatal conductance of the drought sensitive variety were more affected by soil drying than after being acclimated to $25^{\circ} \mathrm{C}$. Consequently increased temperature could exacerbate the impact of drought stress in sunflower with some genotypic differences to explore.

Conroy et al. (1988) evidenced the role of $\mathrm{CO}_{2}$ in the sunflower acclimation to water deficit. The authors observed that plants were more drought-tolerant when water was withheld under conditions that favor osmotic adjustment, namely when water deficits were slowly imposed or when $\left[\mathrm{CO}_{2}\right]$ was higher than $340 \mathrm{ppm}$. As water deficit increases, both leaf conductance to $\left[\mathrm{CO}_{2}\right]$ and the capacity of the mesophyll to fix $\mathrm{CO}_{2}$ decline. Osmotic adjustment occurred during drought in expanded leaves, which had been continuously exposed to $660 \mathrm{ppm}$ or had been previously acclimated to drought. The effect was greatest when the treatments were combined and was negligible in non-acclimated plants grown at $340 \mathrm{ppm}$ of $\mathrm{CO}_{2}$.

Vanaja et al. (2011) assessed the influence of enhanced $\left[\mathrm{CO}_{2}\right](700 \mathrm{ppm})$ under both well-watered and drought stress conditions on plant water status, gas exchange and various root and shoot parameters of sunflower crop plants grown in open top chambers (Tab. 2). Root volume showed a positive response $(+146 \%)$ with elevated $\left[\mathrm{CO}_{2}\right]$. The leaf water potential, stomatal conductance and transpiration showed a decreasing trend with drought stress and elevated $\left[\mathrm{CO}_{2}\right]$ resulted in higher net photosynthetic rates under drought stress. Therefore a beneficial effect of elevated $\left[\mathrm{CO}_{2}\right]$ by ameliorating the adverse effects of drought stress was confirmed in sunflower. Tezara et al. (2002) concluded that elevated $\left[\mathrm{CO}_{2}\right]$ only marginally increased net photosynthesis with limited effects on metabolism of plants growing under water deficit; however, by slowing plant transpiration, $\mathrm{CO}_{2}$ fertilization decreased the rate and severity of water deficit.

\subsection{Multiple stress approach}

A novel approach has recently been undertaken to model the impact of multiple abiotic stresses on sunflower oil yield (Mangin et al., 2016). In this article, the authors developed stress indicators to characterize 14 environments for three abiotic stresses (cold, drought, and nitrogen) using the SUNFLO crop model and phenotypic variations of three commercial varieties. The computed plant stress indicators at variety level better explained yield variation than descriptors at the climatic or crop levels. The impact of stresses could be estimated to $347 \mathrm{~kg} \mathrm{ha}^{-1}$ per day of cold stress, $137 \mathrm{~kg} \mathrm{ha}^{-1}$ per day of drought and $247 \mathrm{~kg} \mathrm{ha}^{-1}$ per $\mathrm{kg}$ of non-absorbed nitrogen. The genetic study based on the responses of 317 sunflower lines showed a strong genetic correlation between tolerance to drought and nitrogen but not between cold tolerance and the other abiotic stressors. This pioneer study performed in a French multi-environment trial network, showed that the cumulated cold stress was equivalent to 10 days and the cumulated drought stress to 35 days on average. Therefore, this indicates that although cold stress (during the vegetative period) has the largest relative impact on oil yield, drought stress was globally the most limiting factor in this multi-environment trial similarly to most sunflower cultivation areas.

\section{Climate change and pathogens}

Climate change could influence the development of pathogens, host resistance and host-pathogen interaction (Coakley et al., 1999). Direct or indirect impacts (via canopy change) of climate change on sunflower disease complex are expected. However, very few information has been produced for sunflower diseases comparatively to cereals for instance (Gulya et al., 1997; Debaeke et al., 2014).

Primary infection could be limited by the lack of precipitation and evapotranspiration increase. To infect the plants, downy mildew (Plasmopara halstedii) requires about $50 \mathrm{~mm}$ of free water during the 10 days surrounding planting date (Tourvieille de Labrouhe et al., 2000). Sclerotinia head rot (Sclerotinia sclerotiorum) needs at least $39 \mathrm{~h}$ of free water for infecting significantly the florets (Lamarque, 1983). Phoma Black stem (Phoma macdonaldii) requires free water at the trough level for significant stem infection (Seassau et al., 2010). Phomopsis stem canker (Phomopsis/ Diaporthe helianthi) will develop initial leaf lesions if relative moisture exceeds $90 \%$ during $36 \mathrm{~h}$ within canopy. High temperatures or elevated VPD could slow down or stop the growth of fungi in the tissues as their thermal optimum often ranges from 15 to $25^{\circ} \mathrm{C}$. Several successive days with $T_{\max }>32^{\circ} \mathrm{C}$ could be lethal for Phomopsis (Delos and Moinard, 1997).

At the same time some pathogens could be promoted by hotter and dryer conditions. Macrophomina phaseolina could be stimulated by low soil water content and temperatures within $28-30{ }^{\circ} \mathrm{C}$ range (Sarova et al., 2003). Premature ripening due to Phoma could be enhanced by dry conditions after flowering (Seassau et al., 2010).

The weakest vegetative growth of sunflower exposed to early soil water deficit could reduce the risk of primary infection by fungi that directly cause damage to leaves and stems (Debaeke et al., 2014). More precipitation in winter and elevated $\left[\mathrm{CO}_{2}\right]$ could promote plant growth and favor the development of associated diseases.

If sunflower moves northward to be grown in new environments that are free of inoculum, more limited attacks are expected in a first time especially if sunflower is grown less frequently as a break crop.

Ecological conditions in the future will be probably less prone to the diseases responsible of yield losses today. But some dominance changes may occur between pathogens (and pathotypes) according to their thermal preferences and their dependency to free water. According to Vear (2016), climatic 


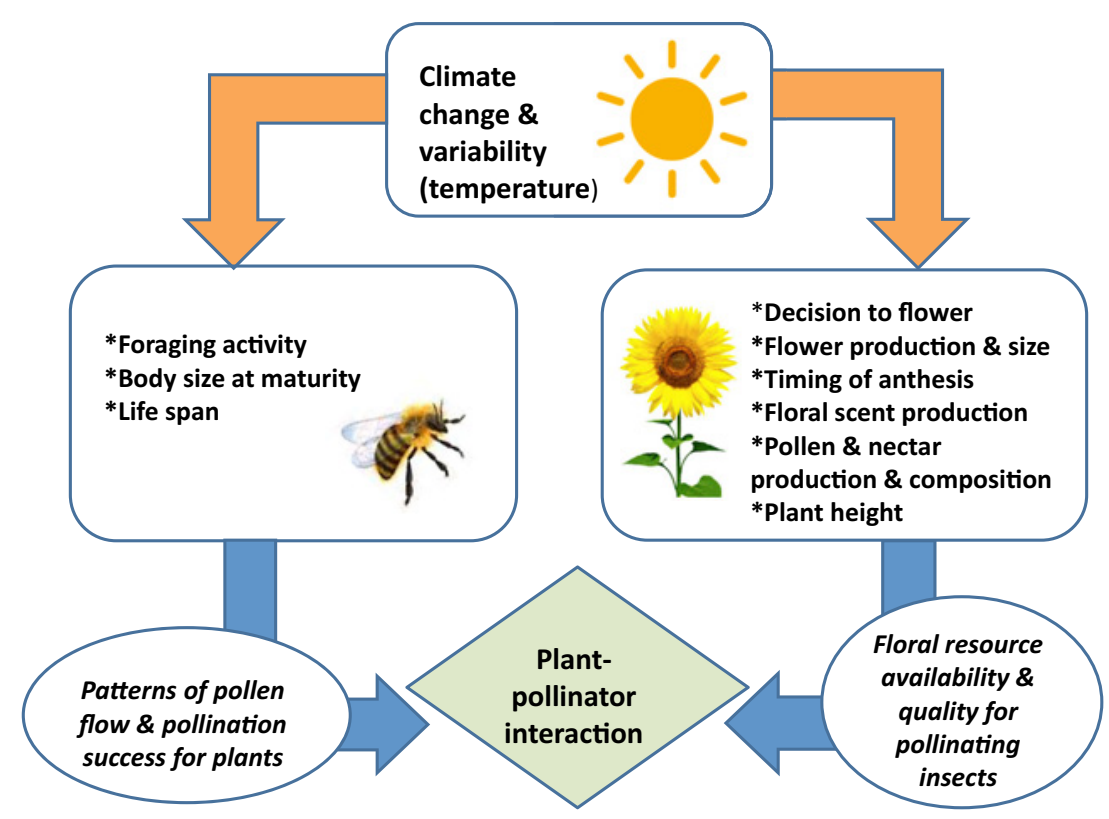

Fig. 3. Framework showing the impact of climate warming on the flowering process and insect activity and demography with consequences on floral resources and pollination success, both terms shaping the plant-pollinator networks (from Scaven and Rafferty, 2013).

change may be involved in the recent development of Orobanche cumana in France, since higher temperatures and absence of rainfall could favor broomrape development in sunflower. Pathogens with long conservation forms in the soil (e.g., sclerotia) could better tolerate unfavorable periods. The detrimental effect of systemic pathogens which block the vessels could be reinforced if plants are suffering more intensely from water shortage in the future.

The development of models coupling crop growth and fungal epidemics in relation with crop management and climatic conditions has to be pursued to be able to predict the injury profile and crop damage in future conditions.

\section{Climate change and pollinators}

Sunflower, as an allogamic plant, needs insects on flowering, especially the honeybees and bumblebees for seed production (De Grandi-Hoffman and Watkins, 2000; Oz et al., 2009; Chamer et al., 2015). Breeding system of selfincompatibility and not well-adapted pollen type hinder the process of wind-pollination. Numerous experiments have found that a seed set as low as 10-20\% results when pollinators are absent and plants self-pollinate, compared to up to $90 \%$ seed set in flower heads accessible to pollinators. However, cultivars have different levels of self-fertility, and many modern sunflowers are fully self-fertile. Cross-pollination may still be preferred, as it appears to give higher yields and better quality in terms of oil content. At the same time, collecting nectar and pollen by honeybees in sunflower crops is also essential to apiculture (Delaplane and Mayer, 2000). Unlike other insects, bees visit a great number of flowers to fulfill the needs of their colony assisting pollination by the way (Müller et al., 2006).

Temperature, precipitation, and extreme events associated to climate change could modify the activity of pollinators
(Kjøhl et al., 2011). Having different climatic requirements, pollinators and plants may therefore respond differently to changes in ambient temperature (Scaven and Rafferty, 2013). For example, increased spring temperatures may postpone plant flowering time while pollinators might be unaffected. As stated before, pollen fertility may be greatly reduced at high temperatures (Astiz and Hernández, 2013), which increases the importance of prompt pollination of self-pollinated varieties during hot weather. Water stress resulting from climate change may decrease flower numbers and nectar production. Extreme climate events might have detrimental effects on both crop plants and pollinator populations. High temperatures, long periods of heavy rain and late frost may affect pollinator activity either by reducing population sizes or by affecting insect activity patterns. Sunny days with low wind speed and intermediate temperature are optimal foraging conditions for pollinators. This was illustrated by Scaven and Rafferty (2013) in Figure 3: both physiological responses of flowering plants (on one side) and activity of insect pollinators (on the other side) can be modified by climate warning; these changes in turn will affect floral resources and pollination success for mutualists, hence shaping plant-pollinator networks.

There is still clear evidence of declines in both wild and domesticated pollinators (e.g. honey bees) (Potts et al., 2010). Pollination is under threat from different kinds of environmental pressures including habitat loss and fragmentation, insecticides, pathogens, alien species, climate change and the interactions between them (Potts et al., 2010). Pollinator declines can result in loss of pollination services which have important negative ecological and economic impact that could significantly affect crop production and food security (Gallai et al., 2009). Because of cross-pollination in sunflower, seed production activity (for hybrids), and commercial grain production could be both affected by decline associated to climate change and other causes (Chamer et al., 2015). 


\section{Crop adaptation to climate change}

\subsection{Genetics and plant breeding}

Plant breeding is considered to be a substantial tool for adaptation strategies to climate change (Ceccarelli et al., 2010). Breeding for new varieties better adapted to thermal shocks (heat, cold) and drought is often suggested as the major long-term adaptation. The breeding strategies aim at improved water efficiency, improved drought stress tolerance, and increased responsiveness to higher atmospheric $\left[\mathrm{CO}_{2}\right]$ (Ceccarelli et al., 2010; Ziska et al., 2012). However, prospective results of plant breeding are unforeseeable and the impact assessment strongly depends on the assumptions made on breeding progress (Graß et al., 2015).

During the past fifteen years, the sunflower yield increase through genetic advance has been slower than before, suggesting that current resources and breeding methods might not bring suitable solutions in a context of climate change (Vear, 2016). In order to face the challenges of delivering safe and high-quality food in a sustainable manner while maintaining yield and stability across different environments, a paradigm shift is needed in sunflower breeding.

The recent availability of the genome sequence (www. heliagene.org) of Helianthus annuus together with the breakthrough of the new breeding technologies in other crops (reviewed in Ricroch and Henard-Damave, 2016) is offering a favorable context to reinforce, through an optimization of the hybrid breeding process, the competitiveness of sunflower varieties. In addition to these novel technological resources, the large genetic diversity of sunflowers within $H$. annuus and across the Helianthus genius remains a very promising and largely untapped reservoir of new alleles to adapt sunflower varieties to social needs.

In this context, there is a great interest for breeding sunflower with high yield stability across different drought scenarios varying in the timing and quantity of water availability. Major actors in sunflower genomics from Canada, USA and France develop since a decade large genomics projects aiming at providing to the scientific community and breeders the necessary tools and resources to fulfill it.

More specifically in France, 15 partners including nine public laboratories with multi-disciplinary expertise spanning from social sciences, agronomy, genetics, and genomics, mainly from INRA, five major sunflower breeding companies (Caussade Semences, Maisadour Semences, RAGT2n, Soltis, and Syngenta), a biotech company (Biogemma) and the French technical institute in charge of oil-protein crops (Terres Inovia) joined within the SUNRISE (SUNflower Resources to Improve yield Stability in a changing Environment) consortium in an unprecedented effort over eight years (http://www. sunrise-project.fr/en/).

The project develops two approaches to identify the physiological, molecular and genetic components of resilience of sunflower hybrids to environmental variation with a special focus on water stress in the context of climate change (Debaeke et al., 2015). First, the SUNRISE researchers develop a combined approach of crop modeling and quantitative genetics. On one hand, they take advantage of the ecophysiological processes represented in the SUNFLO crop model to estimate an average stress of control varieties in a multi-environment trial. This allows estimate the reaction norms of a panel of hybrids and identifies by a Genome-Wide Association Study the genomic loci controlling drought, cold and nitrogen stress tolerance. On the other hand, they identify the genomic loci controlling genotypic parameters of the SUNFLO crop model and predict yield and oil content of virtually recombining genotypes in a range of present and future climatic scenarios.

Secondly, SUNRISE researchers develop a systems biology approach to identify the molecular and genetic processes involved in drought tolerance and specially those allowing the systemic emergence of tolerance as a result of heterosis. For this, they produce a thorough molecular description of drought response in different organs (roots, leaves, and seeds) at the epigenetic, transcriptomic, proteomic, and metabolomic levels in various tolerant and sensitive genotypes including inbred lines and hybrids. Inference of the network describing these genetic interactions might allow identifying network patterns that trigger heterosis for drought tolerance. This second approach will produce some basic knowledge on drought tolerance that will be implemented in quantitative genetic models to improve Genome-Wide Association Studies (GWAS) approaches described above and Genomic Prediction of complex traits such as yield and tolerance to the studied abiotic stresses.

Altogether, these complementary approaches will accelerate sunflower hybrid process and help building new gene pools that will optimize their specific combining ability for productivity and stress tolerance in the context of climate change.

\subsection{Adaptation of cultural practices}

Short-term strategies have been identified from current practices to take advantage of more favorable growing conditions or to offset negative impacts: shifting sowing dates, changing cultivars (earliness), revising soil management, fertilization, and plant protection practices, introducing or expanding irrigation. Crop management still offers a range of opportunities to cope with drought-prone conditions (Debaeke and Aboudrare, 2004).

In sunflower, planting date could be anticipated to escape water stress at flowering and during grain filling. In some Mediterranean regions, sunflower can be planted in late autumn or winter with good results in water use efficiency and yield (Gimeno et al., 1989; Soriano et al., 2004). In northern parts, earlier sowing date in spring was attempted with sometimes-unsuccessful results (Alline, 2009). Varieties adapted to early planting with increased vigor should be selected to take advantage of this practice (Houmanat et al., 2016). Without irrigation, the search and use of cultivars with lower base temperatures and shorter thermal times for emergence will become of great importance. The compensation of reduced crop duration with increasing temperature could be searched by using long cycle cultivars combined with early sowing date.

Crop models have been applied in given situations or at a regional scale to simulate impacts of climate change on yield as a preliminary task for simulating possible adaptations. Guilioni et al. (2010) using STICS model recommended to choose latematuring cultivars and early planting with some perspectives to increase yield in France. In south Italy, Tubiello et al. (2000) simulated $15 \%$ yield increase when sowing 2 weeks earlier 
than currently. Donatelli et al. (2015) simulated simple technical adaptations with CropSyst model. Sowing date was shifted by either bringing forward or delaying sowing by either 10 or 20 calendar days with respect to the baseline sowing date. The other factor was the length of the biological cycle as a proxy for simulating varieties from different maturity groups. Growing degree-days was manipulated to get a realistic variation of flowering and physiological maturity. These authors concluded that adaptation for rainfed sunflower was not completely effective under the 2030 time horizon in a large belt from central France to the most eastern area of Europe. However, it must be pointed out that such results were obtained via simple adjustment of technical management without exploring possibly improved varieties or optimizing input management.

Undoubtedly, supplemental irrigation is an effective way to maintain or increase sunflower yield (and oil concentration) in dry conditions (Rinaldi, 2001; Göksoy et al., 2004; Demir et al., 2006; Champolivier et al., 2011; Klocke et al., 2013) but future water resources could be limited because of competition among users especially in the Mediterranean area (Falloon and Betts, 2010). More water in winter could however be stored (dams, lakes, etc.) for securing summer irrigation when possible.

Rainfed sunflower crop production in Mediterranean environments depends to a large extent on strategies that avoid the intense summer drought. The use efficiency of scarce water resources should be increased by promoting soil conservation techniques, e.g., mulching in no-till systems for reducing soil runoff and evaporation as was attempted in semi-arid regions for sunflower (Aboudrare et al., 2006).

Crop diversification (at field, farm or territory level) could be recommended as a self-insurance measure to cope with more uncertain and fluctuant conditions and bring resilience to the system. Sunflower could be more present in the situations where water resources are scarce. Double cropping could benefit from the longer cropping duration on an annual basis (Graß et al., 2015). Very early sunflower varieties could be planted after oilseed rape, barley or pea completing their cycle in late spring. However, irrigation will be absolutely required for crop establishment while summer water availability could be restricted in some areas.

Model-based tools and site-specific technology could be developed to optimize, support, and secure farmer's decisions. For example, the decision of the cultivar to be cropped (along with adapted management options) could be made in accordance with the most probable type of stress patterns occurring in the considered location. Such tool would allow a better spatial management of the genetic diversity, aiming to reduce genotype-phenotype mismatches thereby increasing production and stability of the target population of environments. We recently conducted a feasibility study where crop modeling was used to amplify the pedo-climatic variability experienced in cultivar evaluation networks and pointed that this approach allows recommending varieties according to environment types (Casadebaig et al., 2016). Provided that simulation models feature previously detailed formalisms to deal with new environmental conditions, simulation-based approaches would be useful to explore potential adaptations to climate change (ideotype design, best management practices, etc.). Adaptation could range from tactical fine-tuning to deep changes in the nature of cropping systems with impacts
Table 3. Inputs used for sunflower cultivation in France, nitrous oxide and GHG emissions.

\begin{tabular}{llc}
\hline $\begin{array}{l}\text { Inputs and nitrous } \\
\text { oxide emissions }\end{array}$ & $\begin{array}{l}\mathrm{GHG} \text { emissions } \\
\left.\text { (kg eq. } \mathrm{CO}_{2} \mathrm{ha}^{-1}\right)\end{array}$ \\
\hline Mineral N fertilizers & $38 \mathrm{~kg} \mathrm{~N} \mathrm{ha}^{-1}$ & 200.6 \\
Mineral P fertilizers & $29 \mathrm{~kg} \mathrm{P}_{2} \mathrm{O}_{5} \mathrm{ha}^{-1}$ & 16.6 \\
Mineral K fertilizers & $22 \mathrm{~kg} \mathrm{~K}_{2} \mathrm{O} \mathrm{ha}^{-1}$ & 11.6 \\
Pesticides & $3 \mathrm{~kg} \mathrm{ha}^{-1}$ & 23.1 \\
Seeds & $4 \mathrm{~kg} \mathrm{ha}^{-1}$ & 8.1 \\
Fuel & $67 \mathrm{ha}^{-1}$ & 206.0 \\
Seed drying & $354 \mathrm{MJ} \mathrm{ha}^{-1}$ & 9.3 \\
Nitrous oxide & $0.91 \mathrm{~kg} \mathrm{~N}^{-\mathrm{N}_{2}} \mathrm{O} \mathrm{ha}$ & 422.2 \\
Total & & $\mathbf{8 9 7 . 6}$ \\
\hline
\end{tabular}

GHG emissions were calculated from mean input applications in France (BIO IS, 2010), the emission factors for the production and transportation of inputs used in France and from the tier 1 method of IPCC to estimate nitrous oxide emissions (from De Klein et al., 2006).

downstream on land use and agricultural sector activity (machinery, inputs, market).

\section{Reduction of GHG emissions with sunflower cropping}

On average, the total emission of greenhouse gas (GHG) of sunflower in France is about $900 \mathrm{~kg} \mathrm{CO}_{2} \mathrm{eq} \mathrm{ha}^{-1}$, according to a calculation based on the average input applications in France (BIO IS, 2010), the emission factors for the production and transportation of inputs used in France and from the tier 1 method of IPCC to estimate direct and indirect nitrous oxide emissions (De Klein et al., 2006) (Tab. 3). The emissions of nitrous oxide $\left(\mathrm{N}_{2} \mathrm{O}\right)$ account for almost half of the total GHG emissions, while the fuel consumption and the mineral $\mathrm{N}$ fertilizers are respectively responsible for $23 \%$ and $22 \%$ of the total. Overall in sunflower, almost $70 \%$ of the GHG emissions arise from $\mathrm{N}$ applications because the tier 1 method calculates $\mathrm{N}_{2} \mathrm{O}$ emissions as a percentage of the amount of $\mathrm{N}$ applied on the field. Hence, the reduction of GHG emissions in sunflower should focus on both the improvement of $\mathrm{N}$ efficiency, in order to decrease the amount of $\mathrm{N}$ fertilization, and on the control of $\mathrm{NO}_{3}{ }^{-}$leakage and $\mathrm{NH}_{3}$ emissions because those $\mathrm{N}$ leakages from the field result in indirect $\mathrm{N}_{2} \mathrm{O}$ emissions. Factors that control some soil properties, especially soil humidity and $\mathrm{pH}$, could also contribute to decrease GHG emissions because they have a major role on $\mathrm{N}_{2} \mathrm{O}$ emissions (Granli and $\mathrm{B} \varnothing \mathrm{ckman}$, 1994), but they are not taken into account in the tier 1 method. The reduction of fuel consumption, which is mainly due to soil tillage, would also significantly contribute to decrease the total GHG emission of sunflower.

The same pattern of GHG emissions is also observed in the main other crops cultivated in France (Fig. 4). However, the shares of $\mathrm{N}$ fertilizer and $\mathrm{N}_{2} \mathrm{O}$ emissions are higher in other crops, compared to sunflower, because the amounts of $\mathrm{N}$ applications are greater: $38 \mathrm{~kg} \mathrm{~N} \mathrm{ha}^{-1}$ in sunflower (Tab. 3) vs. $97-189 \mathrm{~kg} \mathrm{~N} \mathrm{ha}^{-1}$ in other crops (data not shown). Hence, the total emissions per hectare of other crops are 3-3.6 fold greater than that calculated for sunflower. For this reason, cultivating 


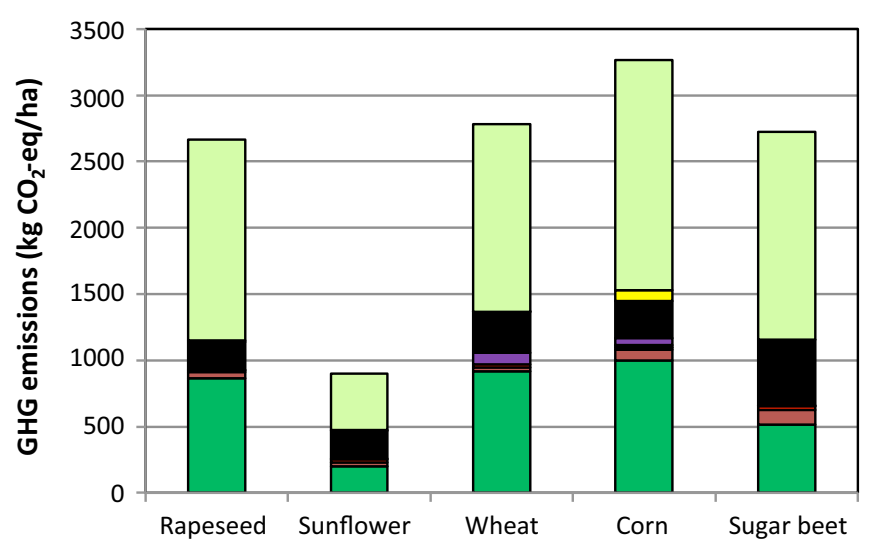

\begin{tabular}{|c|c|c|c|}
\hline$\square \mathrm{N}$ fertilizer & $\square$ PK fertilizer & $\square$ Pesticides & $\square$ Irrigation \\
\hline$\square$ Seeds & Fuel & $\square$ Seed drying & $\square$ Nitrous oxide \\
\hline
\end{tabular}

Fig. 4. GHG emissions of sunflower compared to other crops (from BIO IS, 2010).

sunflower is an effective way to produce oilseeds with low GHG emissions, even though its seed yield is relatively low: the seed yields taken into account in the calculations, which are representative of the average values in France, are $2.39 \mathrm{tha}^{-1}$ for sunflower and $3.28 \mathrm{tha}^{-1}$ for rapeseed, resulting respectively in $376 \mathrm{~kg} \mathrm{CO}_{2} \mathrm{eq} \mathrm{t}^{-1}$ of seeds and $812 \mathrm{~kg} \mathrm{CO}_{2}$ eq t$^{-1}$ of seeds (data not shown).

\section{Conclusions}

Sunflower yield was simulated to potentially improve at northern latitudes with climate change, but with negative effects on yield at southern latitudes. By 2030 the AVEMAC analysis (Donatelli et al., 2012) indicates potential decreases of production in various areas (southern and eastern Europe), if adaptation to climate change is not taken into account. In the next future (2050), the elevated $\left[\mathrm{CO}_{2}\right]$ in the atmosphere could compensate for negative impacts of high temperatures, water stress and reduced crop duration but the $\mathrm{CO}_{2}$ fertilization effect will not prevent yield decrease at 2070-2100 horizon (Guilioni et al., 2010). Numerous uncertainties still exist concerning biodiversity and biotic factors (birds, insects, soil macrofauna, fungi, etc.) that could affect sunflower production in the future. A wide range of genetic and agronomic adaptations have to be evaluated and combined at field, farm and landscape levels.

More attention should be paid on sunflower in future cropping systems as oil-protein, environmentally friendly crop, adapted to low-input production. Several opportunities for sunflower emerged with climate and global change:

- as a low emitter of greenhouse gases (low input crop),

- as a spring/summer break crop in (winter) cereal-based rotations of central and northern Europe (less pesticide use, mechanical control of fall emerging weeds, deep root exploration, etc.),

- as a possible double crop (very early cultivars) after barley, pea, oilseed rape contributing to $\mathrm{C}$ sequestration,

- as a C3 crop, benefiting from " $\mathrm{CO}_{2}$ fertilization" (higher photosynthesis activity) and increasing water-use efficiency (lower water loss),
- as a (moderately) drought-tolerant crop, which can be grown without systematic irrigation, and be adopted in conditions where irrigation water is less available.

The future of sunflower in Europe is probably related to its potential adaptation to climate change (stress escaping, northward shift, double cropping, etc.) but also to its competitiveness and attractiveness for food and energy which must be enhanced through research and public policy.

\section{Disclosure of interest}

None declared.

Acknowledgments. This study was supported by several grants from the Agence Nationale de la Recherche through PIA SUNRISE project (ANR-11-BTBR-0005) and from INRA through Metaprogram ACCAF (CLIF project).

\section{References}

Aboudrare A, Debaeke P, Bouaziz A, Chekli H. 2006. Effects of soil tillage and fallow management on soil water storage and sunflower production in a semiarid Mediterranean climate. Agric Water Manag 83: 183-196.

Ahmad R, Waraich EA, Ashraf MY, Ahmad S, Aziz T. 2014. Does nitrogen fertilization enhance drought tolerance in sunflower? A review. J Plant Nutr 37: 942-963.

Ainsworth EA, Long SP. 2005. What have we learned from 15 years of free-air $\mathrm{CO}_{2}$ enrichment (FACE)? A meta-analytic review of the responses of photosynthesis, canopy properties and plant production to rising $\mathrm{CO}_{2}$. New Phytol 165: 351-372.

Ainsworth EA, Leakey ADB, Ort DR, Long SP. 2008. FACE-ing the facts: inconsistencies and interdependence among field, chamber and modeling studies of elevated $\left(\mathrm{CO}_{2}\right)$ impacts on crop yield and food supply. New Phytol 179: 5-9.

Alline C. 2009. Modélisation écophysiologique et analyse génétique pour la recherche de génotypes de tournesol adaptés aux basses températures causées par des semis précoces, $\mathrm{PhD}$ Thesis. France: INP Toulouse.

Andrianasolo FN, Casadebaig P, Champolivier L, Maza E, Maury P, Debaeke P. 2014. Prediction of sunflower grain oil concentration as a function of variety, crop management and environment by the means of statistical models. Eur J Agron 54: 84-96.

Andrianasolo FN, Debaeke P, Champolivier L, Maury P. 2016a. Analysis and modelling of the factors controlling seed oil content in sunflower: a review. OCL 23 (2): D206.

Andrianasolo FN, Casadebaig P, Langlade N, Debaeke P, Maury P. 2016b. Effects of growth stage and leaf ageing on transpiration and photosynthesis response to soil water stress in sunflower. Funct Plant Biol 43: 797-805.

Astiz V, Hernández LF. 2013. Pollen production in sunflower(Helianthus annuus L.) is affected by air temperature and relative humidity during early reproductive growth. Phyton (Buenos Aires) 82: 297-302.

Bellarby J, Wattenbach M, Tuck G, Glendining MJ, Smith P. 2010. The potential distribution of bioenergy crops in the UK under present and future climate. Biomass Bioenergy 34: 1935-1945.

BIO IS. 2010. Analyses de Cycle de Vie appliquées aux biocarburants de première génération consommés en France - Rapport final. Coordination ADEME, $236 \mathrm{p}$.

Brisson N, Gary C, Justes E, et al. 2003. An overview of the crop model STICS. Eur J Agron 18: 309-332. 
Brisson N, Gate P, Gouache D, Charmet G, Oury FX, Huard F. 2010. Why are wheat yields stagnating in Europe? A comprehensive data analysis for France. Field Crops Res 119: 201-212.

Cabelguenne M, Debaeke P. 1998. Experimental determination and modelling of the soil water extraction capacities of maize, sunflower, soya bean, sorghum and wheat. Plant Soil 202: 175-192.

Cabelguenne M, Debaeke P, Bouniols A. 1999. EPIC phase, a version of the EPIC model simulating the effects of water and nitrogen stress on biomass and yield, taking account of developmental stages: validation on maize, sunflower, sorghum, soybean and winter wheat. Agric Syst 60: 175-196.

Caldeira CF, Jeanguenin L, Chaumont F, Tardieu F. 2014. Circadian rhythms of hydraulic conductance and growth are enhanced by drought and improve plant performance. Nat Commun 5: 5365.

Carter TR, Porter JH, Parry ML. 1991. Climatic warming and crop potential in Europe: prospects and uncertainties. Glob Environ Change 1: 291-312.

Casadebaig P, Debaeke P, Lecoeur J. 2008. Thresholds for leaf expansion and transpiration response to soil water deficit in a range of sunflower genotypes. Eur J Agron 28: 646-654.

Casadebaig P, Guilioni L, Lecoeur J, Christophe A, Champolivier L, Debaeke P. 2011. SUNFLO, a model to simulate genotypespecific performance of sunflower crop in contrasting environments. Agric For Meteorol 151: 163-178.

Casadebaig P, Mestries E, Debaeke P. 2016. A model-based approach to assist variety evaluation in sunflower crop. Eur J Agron 81: 92-105.

Ceccarelli S, Grando S, Maatougui M, et al. 2010. Plant breeding and climate changes. J Agric Sci 148: 627-637.

Chamer AM, Medan D, Mantese AI, Bartoloni NJ. 2015. Impact of pollination on sunflower yield: is pollen amount or pollen quality what matters? Field Crops Res 176: 61-70.

Champolivier L, Debaeke P, Merrien A. 2011. Pourquoi irriguer le tournesol, une culture réputée tolérante à la sécheresse ? Innov Agron 14: 151-164.

Chapman SC, Hammer GL, Meinke H. 1993. A sunflower simulationmodel: 1. Model development. Agron J 85: 725-735.

Cheng W, Sims DA, Luo Y, Coleman JS, Johnson DW. 2000. Photosynthesis, respiration, and net primary production of sunflower stands in ambient and elevated atmospheric $\mathrm{CO}_{2}$ concentrations: an invariant NPP:GPP ratio? Glob Change Biol 6: 931-941.

Chimenti CA, Hall AJ. 2001. Grain number responses to temperature during floret differentiation. Field Crops Res 72: 177-185.

Chimenti CA, Hall AJ, López MS. 2001. Embryo-growth rate and duration in sunflower as affected by temperature. Field Crops Res 69: 81-88.

Chimenti CA, Pearson J, Hall AJ. 2002. Osmotic adjustment and yield maintenance under drought in sunflower. Field Crops Res 75: 235-246.

Coakley SM, Scherm H, Chakraborty S. 1999. Climate change and plant disease management. Annu Rev Phytopathol 37: 399-426.

Connor DJ, Hall AJ. Sunflower physiology. In: Schneiter AA, ed. Sunflower Technology and Production. Madison, Wisconsin, USA: ASA, 1997, pp. 113-182.

Conroy JP, Virgona JM, Smillie RM, Barlow EW. 1988. Influence of drought acclimation and $\mathrm{CO}_{2}$ enrichment on osmotic adjustment and chlorophyll a fluorescence of sunflower during drought. Plant Physiol 86: 1108-1115.

Constantin J, Willaume M, Murgue C, Lacroix B, Therond O. 2015. The soil-crop models STICS and AqYield predict yield and soil water content for irrigated crops equally well with limited data. Agric For Meteorol 206: 55-68.
Cook S. 2009. Sunflowers and climate change. http://www.warwick. ac.uk/go/climatechange/innovation-network.

Debaeke P, Aboudrare A. 2004. Adaptation of crop management to water-limited environments. Eur J Agron 21: 433-446.

Debaeke P, Bergez JE, Leenhardt D. 2008. Perspectives agronomiques et génétiques pour limiter ou réguler la demande en eau d'irrigation. La Houille Blanche, Revue Internationale de l'Eau 2008-6: 17-25.

Debaeke P, Mestries E, Desanlis M, Seassau C. 2014. Effects of crop management on the incidence and severity of fungal diseases in sunflower. In: Arribas JE, ed. Sunflowers: growth and development, environmental influences and pests/diseases. New York, USA: Nova Science Pubs, pp. 201-226.

Debaeke P, Coque M, Muños S, et al. 2015. Breeding for sunflower hybrids adapted to climate change: the SUNRISE collaborative and multi-disciplinary project. In: Proceedings of Climate-Smart Agriculture 2015, Global Science Conference, Montpelier, 16-18 March, 2015.

De Grandi-Hoffman G, Watkins JC. 2000. The foraging activity of honey bees Apis mellifera and non-Apis bees on hybrid sunflowers (Helianthus annuus) and its influence on crosspollination and seed set. J Apic Res 39: 37-45.

De Klein C, Novoa RSA, Ogle S, et al. 2006. Chapter $11-\mathrm{N}_{2} \mathrm{O}$ emissions from managed soils, and $\mathrm{CO}_{2}$ emissions from lime and urea application. In: 2006 IPCC Guidelines for National Greenhouse Gas Inventories.

De la Haba P, De la Mata L, Molina E, Agüera E. 2014. High temperature promotes early senescence in primary leaves of sunflower (Helianthus annuus L) plants. Can J Plant Sci 94: 659-669.

De la Mata L, Cabello P, de la Haba P, Agüera E. 2012. Growth under elevated atmospheric $\mathrm{CO}_{2}$ concentration accelerates leaf senescence in sunflower (Helianthus annuus L) plants. J Plant Physiol 169: 1392-1400.

De la Mata L, De la Haba P, Alamillo JM, Pineda M, Agüera E. 2013. Elevated $\mathrm{CO}_{2}$ concentrations alter nitrogen metabolism and accelerate senescence in sunflower (Helianthus annuus L) plants. Plant Soil Environ 59: 303-308.

Delaplane KS, Mayer DF. 2000. Crop pollination by bees. New York: CABI.

Delos M, Moinard J. 1997. Phomopsis du tournesol: nouveaux progrès dans la prévision des épidémies. Phytoma 492: 17-21.

Demir AO, Göksoy AT, Buyukcangaz H, Turan ZM, Koksal ES. 2006. Deficit irrigation of sunflower (Helianthus annuus L) in a sub-humid climate. Irrig Sci 24: 279-289.

Donatelli M, Duveiller G, Fumagalli D, et al. 2012. Assessing agriculture vulnerabilities for the design of effective measures for adaption to climate change (AVEMAC project) European Union. Luxembourg: Joint Research Centre, Publications Office of the European Union, doi: 102788/16181.

Donatelli M, Srivastava AK, Duveiller G, Niemeyer S, Fumagalli D. 2015. Climate change impact and potential adaptation strategies under alternate realizations of climate scenarios for three major crops in Europe. Environ Res Lett 10: 075005.

Falloon P, Betts R. 2010. Climate impacts on European agriculture and water management in the context of adaptation and mitigation - the importance of an integrated approach. Sci Total Environ 408: 5667-5687.

Gallai N, Salles JM, Settele J, Vaissière BE. 2009. Economic valuation of the vulnerability of world agriculture confronted with pollinator decline. Ecol Econ 68: 810-821.

Garcia-Lopez J, Lorite IJ, Garcia-Ruiz R, Dominguez J. 2014. Evaluation of three simulation approaches for assessing yield of rainfed sunflower in a Mediterranean environment for climate change impact modelling. Clim Change 124: 147-162. 
García-Vila M, Fereres E, Prieto MH, Ruz C, Soriano MA. 2012. Sunflower. In: Crop yield response to water FAO Irrigation and Drainage, Paper 66.

Gibbons JM, Ramsden SJ. 2008. Integrated modelling of farm adaptation to climate change in East Anglia, UK: scaling and farmer decision-making. Agric Ecosyst Environ 127: 126-134.

Gimeno V, Fernández-Martínez JM, Fereres E. 1989. Winter planting as a means of drought escape in sunflower. Field Crops Res 22: 307-316.

Göksoy AT, Demir AO, Turan ZM, Dagüstü N. 2004. Responses of sunflower (Helianthus annuus L) to full and limited irrigation at different growth stages. Field Crops Res 87: 167-178.

Granli T, Bøckman OC. 1994. Nitrous oxide from agriculture. Nor J Agric Sci supplement No 12: 128.

Graß R, Thies B, Kersebaum KC, Wachendorf M. 2015. Simulating dry matter yield of two cropping systems with the simulation model HERMES to evaluate impact of future climate change. Eur J Agron 70: 1-10.

Griffin KL, Seemann JR. 1996. Plants, $\mathrm{CO}_{2}$ and photosynthesis in the 21st century. Chem Biol 3: 245-254.

Guilioni L, Brisson N, Levrault F. 2010. Eléments sur le changement climatique et la culture de tournesol. Livre Vert du projet Climator (2007-2010). Angers (France): ADEME Editions, pp. 201-212.

Gulya T, Rashid KY, Masirevic SM. 1997. Sunflower diseases. In: Schneiter AA, ed. Sunflower production and technology. Agronomy monograph 35. Madison, WI, USA: Soil Science Society of America.

Harris HC, McWilliams JR, Mason WK. 1978. Influence of temperature on oil content and composition of sunflower seed. Aust J Agric Res 29: 1203-1212.

Harrison PA, Butterfield RE. 1996. Effects of climate change on Europe-wide winter wheat and sunflower productivity. Clim Res 7: 225-241.

Houmanat K, El Fechtali M, Mazouz H, Nabloussi A. 2016. Assessment of sunflower germplasm selected under autumn planting conditions. In: Proceedings of the 19th International Sunflower Conference, Edirne, Turkey, pp. 286-293.

Hui D, Luo Y, Cheng W, Coleman JS, Johnson DW, Sims D. 2001. Canopy radiation- and water-use efficiencies as affected by elevated $\left[\mathrm{CO}_{2}\right]$. Glob Change Biol 7: 75-91

IPCC. 2007. In: Pachauri RK, Reisinger A, eds. Contribution of Working Groups I, II and III to the Fourth Assessment Report of the Intergovernmental Panel on Climate Change. Geneva, Switzerland: IPCC, $104 \mathrm{p}$.

IPCC. 2014. In: Pachauri RK, Meyer LA, eds. Contribution of Working Groups I, II and III to the Fifth Assessment Report of the Intergovernmental Panel on Climate Change. Geneva, Switzerland: IPCC, $151 \mathrm{p}$.

Jablonski LM, Wang X, Curtis PS. 2002. Plant reproduction under elevated $\mathrm{CO}_{2}$ conditions: a meta-analysis of reports on 79 crop and wild species. New Phytol 156: 9-26.

Killi D, Bussotti F, Raschi A, Haworth M. 2016. Adaptation to high temperature mitigates the impact of water deficit during combined heat and drought stress in $\mathrm{C} 3$ sunflower and C4 maize varieties with contrasting drought tolerance. Physiol Plant [Epub ahead of print]. doi: 10.1111/ppl.12490.

Kiniry JR, Blanchet R, Williams JR, Texier V, Jones CA, Cabelguenne M. 1992. Sunflower simulation using the EPIC and Almanac models. Field Crops Res 30: 402-423.

Kjøhl M, Nielsen A, Stenseth NC. 2011. Potential effects of climate change on crop pollination. Rome: FAO, 38 p.
Klocke NL, Currie RS, Tomsicek DJ, Koehn JW. 2013. Sunflower response to irrigation from limited water supplies with no-till management. Trans ASABE 56: 167-175.

Lamarque C. 1983. Conditions climatiques nécessaires à la contamination du tournesol par Sclerotinia sclerotiorum ; prévision des épidémies locales. Bull OEPP 13: 75-78.

Long SP, Ainsworth EA, Leakey ADB, Ort DR. 2006. Food for thought: lower-than-expected crop yield stimulation with rising $\mathrm{CO}_{2}$ conditions. Science 312: 1918-1921.

Lotze-Campen H. 2011. Regional climate impacts on agriculture in Europe. In: Yadav SS, Redden RJ, Hatfield JL, Lotze-Campen $\mathrm{H}$, Hall AE, eds. Crop adaptation to climate change. Chichester, West Sussex (UK): John Wiley and Sons Ltd., pp. $78-83$.

Luo Y, Hui D, Cheng W, Coleman JS, Johnson DW, Sims DA. 2000. Canopy quantum yield in a mesocosm study. Agric For Meteorol 100: 35-48.

Mangin B, Casadebaig P, Cadic E, et al. 2016. Genetic control of plasticity of oil yield for combined abiotic stresses using a joint approach of crop modeling and genome-wide association. Plant Cell Environ (in press).

Martre P, Wallach D, Asseng S, et al. 2015. Multimodel ensembles of wheat growth: many models are better than one. Glob Change Biol 21: 911-925.

Moriondo M, Bindi M. 2007. Impact of climate change on the phenology of typical Mediterranean crops. Ital J Agrometeorol 3: 5-12.

Moriondo M, Giannakopoulos C, Bindi M. 2011. Climate change impact assessment: the role of climate extremes in crop yield simulation. Clim Change 104: 679-701.

Müller A, Diener S, Schnyder S, Stutz K, Sedivy C, Dorn S. 2006. Quantitative pollen requirements of solitary bees: implications for bee conservation and the evolution of bee-flower relationships. Biol Conserv 130: 604-615.

Niemelä TA, Tulisalo UE. 2000. Sunflower hybrids adapted to the finnish growing conditions. In: Proceedings of the 15th International Sunflower Conference, Toulouse (France), N, pp. 22-26.

Olesen JE, Bindi M. 2002. Consequences of climate change for European agricultural productivity, land use and policy. Eur $J$ Agron 16: 239-262.

Olivier D, Bernoux M, Chauveau M, Lucas C, Chazot S. 2016. Étude de l'effet du changement climatique sur le potentiel de développement des productions végétales en Russie, Ukraine, Kazakhstan à moyen terme. Rapport final, BRL Ingénierie, Nimes (France). Étude financée par MAAF, France AgriMer et Intercéréales, $58 \mathrm{p}+$ annexes.

Ottman MJ, Kimball BA, White JW, Wall GW. 2012. Wheat growth response to increased temperature from varied planting dates and supplemental infrared heating. Agron J 104: 7-16.

Oz M, Karasu A, Cakmak I, Goksoy AT, Turan ZM. 2009. Effects of honeybee (Apis mellifera) pollination on seed set in hybrid sunflower (Helianthus annuus L). Afr J Biotechnol 8: 10371043.

Pal M, Chaturvedi AK, Pandey SK, Bahuguna RN, Khetarpal S, Anand A. 2014. Rising atmospheric $\mathrm{CO}_{2}$ may affect oil quality and seed yield of sunflower (Helianthus annuus L). Acta Physiol Plant 36: 2853-2861.

Pankovic D, Sakac Z, Kevresan S, Plesnicar M. 1999. Acclimation to long-term water deficit in the leaves of two sunflower hybrids: photosynthesis, electron transport and carbon metabolism. $J$ Exp Bot 50: 128-138. 
Parent B, Tardieu F. 2012. Temperature responses of developmental processes have not been affected by breeding in different ecological areas for 17 crop species. New Phytol 194: 760-774.

Peltonen-Sainio P, Jauhiainien L, Hakala K, Ojanen H. 2009. Climate change and prolongation of growing season: changes in regional potential for field production in Finland. Agric Food Sci 18: 171-190.

Porter JR, Xie L, Challinor V, et al. 2014. Food security and food production systems. In: Climate change 2014: impacts, adaptation, and vulnerability. Cambridge, UK/New York, USA: Cambridge University Press, pp. 485-533.

Potts SG, Biesmeijer JC, Kremen C, Neumann P, Schweiger O, Kunin WE. 2010. Global pollinator declines: trends, impacts and drivers. Trends Ecol Evol 25: 345-353.

Raes D, Steduto P, Hsiao TC, Fereres E. 2009. AquaCrop-The FAO crop model to simulate yield response to water: II. Main algorithms and software description. Agron J 101: 438-447.

Ricroch AE, Henard-Damave MC. 2016. Next biotech plants: new traits, crops, developers and technologies for addressing global challenges. Crit Rev Biotechnol 36: 675-690.

Rinaldi M. 2001. Application of EPIC model for irrigation scheduling of sunflower in Southern Italy. Agric Water Manag 49: 185-196.

Rinaldi M, Rascio A, Garofalo P. 2015. Sunflower and biomass sorghum photosynthesis response to $\mathrm{CO}_{2}$ enrichment. Rom Agric Res 32: 113-122.

Rondanini D, Savin R, Hall AJ. 2003. Dynamics of fruit growth and oil quality of sunflower (Helianthus annuus L) exposed to brief intervals of high temperature during grain filling. Field Crops Res 83: 79-90.

Rondanini D, Mantese A, Savin R, Hall AJ. 2006. Responses of sunflower yield and grain quality to alternating day/night high temperature regimes during grain filling: effects of timing, duration and intensity of exposure to stress. Field Crops Res 96: 48-62.

Sadok W. 2016. The circadian life of nocturnal water use: when late night decisions help improve your day. Plant Cell Environ 39: 1-2.

Salvi F, Pouzet A. 2010. Étude sur les causes possibles du ralentissement du progrès agronomique en colza d'hiver et en tournesol. CR Académie d'Agriculture de France 96 (3): 24-32.

Sarova J, Kudlikova I, Zalud Z, Veverka K. 2003. Macrophomina phaseolina (Tassi) Goid moving north - temperature adaptation or change in climate? J Plant Dis Prot 110: 444-448.

Scaven VL, Rafferty NE. 2013. Physiological effects of climate warming on flowering plants and insect pollinators and potential consequences for their interactions. Curr Zool 59: 418-426.

Schoppach R, Sadok W. 2013. Transpiration sensitivities to evaporative demand and leaf areas vary with night and day warming regimes among wheat genotypes. Funct Plant Biol 40: 708-718.

Seassau C, Debaeke P, Mestries E, Dechamp-Guillaume G. 2010. Evaluation of $P$. macdonaldii inoculation methods to reproduce sunflower premature ripening. Plant Dis 94: 1398-1404.

Seguin B. 2003. Adaptation des systèmes de production agricole au changement climatique. CR Geosci 335: 569-575.

Seneweera S, Norton RM. 2011. Plant responses to increased carbon dioxide. In: Yadav SS, Redden RJ, Hatfield JL, Lotze-Campen H, Hall AE, eds. Crop adaptation to climate change. Chichester, West Sussex (UK): John Wiley and Sons Ltd., pp. 198-217.
Sims DA, Cheng W, Luo Y, Seemann JR. 1999. Photosynthetic acclimation to elevated $\mathrm{CO}_{2}$ in a sunflower canopy. J Exp Bot 50: 645-653.

Soriano MA, Orgaz F, Villalobos FJ, Fereres E. 2004. Efficiency of water use of early plantings of sunflower. Eur J Agron 21: 465-476.

Srinivasarao C, Kundu S, Shanker AK, et al. 2016. Continuous cropping under elevated $\mathrm{CO}_{2}$ : differential effects on $\mathrm{C} 4$ and $\mathrm{C} 3$ crops, soil properties and carbon dynamics in semi-arid alfisols. Agric Ecosyst Environ 218: 73-86.

Stöckle CO, Donatelli M, Nelson R. 2003. CropSyst, a cropping systems simulation model. Eur J Agron 18: 289-307.

Taub DR, Miller B, Allen H. 2008. Effects of elevated $\mathrm{CO}_{2}$ on the protein concentration of food crops: a meta-analysis. Glob Change Biol 14: 565-575.

Tezara W, Mitchell V, Driscoll SP, Lawlor DW. 2002. Effects of water deficit and its interaction with $\mathrm{CO}_{2}$ supply on the biochemistry and physiology of photosynthesis in sunflower. $J$ Exp Bot 53: 1781-1791.

Todorovic M, Albrizio R, Zivotic L, Abi Saab MT, Stöckle C, Steduto P. 2009. Assessment of AquaCrop, CropSyst, and WOFOST models in the simulation of sunflower growth under different water regimes. Agron J 101: 509-521.

Tourvieille de Labrouhe D, Pilorgé E, Nicolas P, Vear F. 2000. Le mildiou du tournesol. Paris, France: Editions Quae.

Tubiello FN, Donatelli M, Rosenzweig C, Stockle CO. 2000. Effects of climate change and elevated $\mathrm{CO}_{2}$ on cropping systems: model predictions at two Italian locations. Eur J Agron 13: 179-189.

Tuck G, Glendining MJ, Smith P, House JI, Wattenbach M. 2006. The potential distribution of bioenergy crops in Europe under present and future climate. Biomass Bioenergy 30: 183-197.

Valverde P, de Carvalho M, Serralheiro R, Maia R, Ramos V, Oliveira B. 2015. Climate change impacts on rainfed agriculture in the Guadiana riverbasin (Portugal). Agric Water Manag 150: 35-45.

Vanaja M, Yadav SK, Archana G, et al. 2011. Response of C4 (maize) and C3 (sunflower) crop plants to drought stress and enhanced carbon dioxide concentration. Plant Soil Environ 57: 207-215.

Vear F. 2016. Changes in sunflower breeding over the last fifty years. OCL 23 (2): D202.

Villalobos FJ, Hall AJ, Ritchie JT, Orgaz F. 1996. OILCROP-SUN: a development, growth, and yield model of the sunflower crop. Agron J 88: 403-415.

Virgona J, Hubick K, Rawson H, Farquhar G, Downes R. 1990. Genotypic variation in transpiration efficiency, carbon-isotype discrimination and carbon allocation during early growth in sunflower. Funct Plant Biol 17: 207-214.

Yadav SS, Redden RJ, Hatfield JL, Lotze-Campen H, Hall AE, eds. 2011. Crop adaptation to climate change. Chichester, West Sussex (UK): John Wiley and Sons Ltd., 595 p.

Zeng W, Wu J, Hoffman MP, Xu C, Ma T, Huang J. 2016. Testing the APSIM sunflower model on saline soils of Inner Mongolia, China. Field Crops Res 192: 42-54

Ziska LH, Bunce JA, Shimono H, et al. 2012. Food security and climate change: on the potential to adapt global crop production by active selection to rising atmospheric carbon dioxide. Proc $R$ Soc B: Biol Sci 279: 4097-4105.

Cite this article as: Debaeke P, Casadebaig P, Flenet F, Langlade N. 2017. Sunflower crop and climate change: vulnerability, adaptation, and mitigation potential from case-studies in Europe. OCL, 2017, 24(1) D102. 